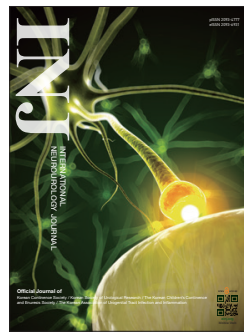

\title{
Management of Urinary Incontinence With Underactive Bladder:
}

\section{A Review}

\author{
Kang Jun Cho, Joon Chul Kim \\ Department of Urology, Bucheon St. Mary's Hospital, College of Medicine, The Catholic University of Korea, Seoul, Korea
}

\begin{abstract}
Urinary incontinence is caused by storage function failure, while underactive bladder (UAB) is caused by a decline in detrusor contractility and voiding dysfunction. As the treatment mechanisms for incontinence and UAB are contrary to each other, it is difficult to treat both incontinence and UAB, and the patient's quality of life can be further degraded. Conventional midurethral sling (MUS), such as transobturator tape or retropubic MUS, introduces a risk of postoperative voiding dysfunction in stress urinary incontinence with UAB. However, there have been several reports about the efficacy and safety of conventional MUS. Adjustable sling procedures, such as transobturator adjustable tape or the Remeex system, have better outcomes than conventional MUS because they control tension both during and after surgery. When voiding dysfunction occurs after incontinence treatment with UAB, voiding symptoms can be improved by various therapeutic modalities. Clean intermittent catheterization is recommended for patients with significant increased postvoid residual volumes or urinary retention. Although pharmacotherapy such as with alpha-blockers or parasympathomimetics can be considered for UAB, there is insufficient evidence of their effect on incontinence with UAB. Future therapies, such as stem cell therapy or gene therapy, may be used to treat incontinence with UAB. The possibility of management urgency urinary incontinence that related to detrusor hyperactivity with impaired contractility using sacral neuromodulation has been suggested. Further research is needed to establish evidence for the efficacy and safety of treatments for incontinence with UAB and improve patient quality of life.
\end{abstract}

Keywords: Urinary incontinence; Urinary bladder, underactive; Therapeutics

- Conflict of Interest: No potential conflict of interest relevant to this article was reported.

\section{INTRODUCTION}

Urinary incontinence has the largest negative effect on patient quality of life among lower urinary tract symptoms (LUTS) [1]. Incontinence can coexist with other lower urinary tract dysfunction, such as overactive bladder $(\mathrm{OAB})$ or underactive bladder (UAB). While OAB can be controlled to a certain extent through pharmacotherapy such as with antimuscarinics, there is a lack of definitive treatment for UAB. In addition, the $\mathrm{UAB}$ treatment mechanism is contrary to that for incontinence, which makes it difficult to treat incontinence with UAB.

Although an expert group defined UAB as a symptom complex related to detrusor underactivity (DU) that is usually characterized by prolonged urination time with or without a sensation of incomplete bladder emptying, usually with hesitancy, reduced bladder filling sensation, slow stream, straining to void, enuresis, and/or stress incontinence [2], its definition has not yet been standardized. Because of the variability in definition, the reported prevalence of incontinence with UAB also varies. A prevalence study of DU and stress urinary incontinence

Corresponding author: Joon Chul Kim (D) https://orcid.org/0000-0002-4019-620X Department of Urology, Bucheon St. Mary's Hospital, College of Medicine, The Catholic University of Korea, 327Sosa-ro, 327beon-gil, Wonmi-gu, Bucheon 14647, Korea

E-mail: kjc@catholic.ac.kr

Submitted: March 6, 2020 / Accepted after revision: April 16, 2020 
(SUI) among elderly patients with LUTS in Korea showed that more than $40 \%$ of women with DU had accompanying SUI [3]. Ong and Kuo [4] performed a preoperative video urodynamic study (UDS) of women with SUI and reported that $19.4 \%$ of the enrolled patients had detrusor overactivity (DO) and 8.4\% had DU.

Conventional treatment for incontinence may result in different outcomes for patients with UAB, and other treatments or a whole new method may be required. This review focuses on treatment options and their outcomes for incontinence with $\mathrm{UAB}$.

\section{PATHOPHYSIOLOGY}

Although the pathophysiology of UAB is not yet clearly defined, the main mechanism is decline in the detrusor contractile function due to myogenic failure, efferent nerve dysfunction, afferent nerve dysfunction, and failure of the central nervous system to coordinate voiding function [5]. Urinary incontinence is caused by a failure of the storage function of the lower urinary tract that is related to abnormal detrusor activity, such as DO or inadequate bladder outlet pressure. Urethral hypermobility and intrinsic sphincter deficiency have been suggested as the major mechanisms of incontinence due to abnormal bladder outlet function [6].

The urodynamic findings of UAB include DU, an acontractile detrusor, and detrusor hyperactivity with impaired contractility (DHIC). Although DHIC is associated with urgency urinary incontinence (UUI), it does not account for much of the UAB population [7]. SUI, a type of urethral sphincter dysfunction, is more likely to be associated with $\mathrm{UAB}$ involving incontinence.

Incontinence treatment requires decreased detrusor pressure or increased bladder outlet pressure, but UAB treatment requires increased detrusor pressure or decreased bladder outlet pressure. Therefore, UAB treatment and incontinence treatment may involve contradictory mechanisms, complicating their combined treatment. Treatments for SUI inhibit urinary leakage by increasing bladder outlet resistance or restoring the natural shape and configuration of the urethral support. One complication, regardless of the type of anti-incontinence surgery, is iatrogenic obstruction, which has an incidence of $2.5 \%-$ $24 \%$ [8]. In patients with SUI and UAB, there is a concern for developing obstructive voiding problems that will require sling revision or removal. There are no clear treatment guidelines for
SUI with UAB. It is important to maintain proper lower urinary tract function by controlling the severity or degree of incontinence and UAB. This should be supported by accurate UDS findings prior to the treatment of incontinence with UAB.

\section{MANAGEMENT}

\section{Conservative Treatment}

Pelvic floor muscle training (PFMT) for patients with urinary incontinence can reduce urine leakage episodes and improve quality of life without increasing negative side effects [9]. While PFMT is the first-line treatment for urinary incontinence, it is not efficacious in moderate or severe incontinence compared to surgical treatment such as a midurethral sling (MUS) [10]. Some studies have shown the potential of PFMT with biofeedback for UAB $[11,12]$. Conservative treatment, such as PFMT alone, may not be effective in patients with UAB incontinence. However, the benefits of conservative treatment may be useful in combination with other treatments, although the evidence remains insufficient.

\section{Conventional Midurethral Sling}

Conventional MUS, which controls SUI by the placement of a mesh at the midurethra through either the obturator or retropubic space, has a long-term subjective cure rate of $43 \%$ to $92 \%$ [13]. However, the efficacy and safety of conventional MUS in patients with SUI coexisting with UAB may be different.

Kim and Kim [14] showed that transobturator tape (TOT) could be installed safely for patients with SUI and DU, with $88 \%$ success and $7 \%$ dissatisfaction rates over more than 2 years of follow-up. In that study, DU was defined by a maximal flow rate (Qmax) of $<15 \mathrm{~mL} / \mathrm{sec}$ and detrusor pressure at maximum flow (PdetQmax) of $<20 \mathrm{~cm} \mathrm{H}_{2} \mathrm{O}$. Preoperative mean postvoid residual volume (PVR) was $16.1 \pm 32.3 \mathrm{~mL}$, and the preoperative mean PdetQmax was $13.1 \pm 4.7 \mathrm{~cm} \mathrm{H}_{2} \mathrm{O}$. The postoperative PVR increased to $26.1 \pm 27.9 \mathrm{~mL}$, which was not clinically significant. Their study showed an increase in PVR of greater than $100 \mathrm{~mL}$ in $7 \%$ of the patients, but the patients improved after 3 to 4 months of medical treatment with alpha-blockers. In another study evaluating the effect of TOT on the voiding phase, the success rate for SUI at mean follow-up of 76 months was similar for the DU group and the control group. However, voiding dysfunction after TOT significantly increased from $18 \%$ to $36 \%$ in the DU group, and de novo voiding dysfunction was significantly more common in the DU group [15]. In that study, 
DU was defined by a projected isovolumetric pressure index (PdetQmax+Qmax) of $<30 \mathrm{~cm} \mathrm{H}_{2} \mathrm{O}$. The preoperative mean PdetQmax of the enrolled patients was $10.6 \pm 5.2 \mathrm{~cm} \mathrm{H}_{2} \mathrm{O}$. They reported that a PdetQmax of $\leq 12 \mathrm{~cm} \mathrm{H}_{2} \mathrm{O}$ was a predictor for postoperative voiding dysfunction in patients with SUI and DU.

Ong and Kuo [4] reported that the outcome of retropubic MUS for SUI was not affected by preoperative bladder dysfunction. The patients with DU in that study had a preoperative mean PVR of $182.2 \pm 291.3 \mathrm{~mL}$ and had looser sling placement at the mid-urethra and adjustment of sling tension by a cough test at $300 \mathrm{~mL}$ of bladder filling. The 10 -year continence rate in DU was $79.4 \%$, which was not different from the outcomes of the patients with stable bladder or DO. Another study elucidating the outcome of retropubic MUS in SUI with DU showed that $76 \%$ of the patients had clinical improvement in their SUI, but $21 \%$ of the patients needed clean intermittent catheterization (CIC) to empty their bladder [16]. DU was defined by a PdetQmax of $<20 \mathrm{~cm} \mathrm{H}_{2} \mathrm{O}$ and a Qmax of $<15 \mathrm{~mL} / \mathrm{sec}$ in that study. The preoperative mean PVR was $186 \pm 150 \mathrm{~mL}$, and the mean PdetQmax was $11.5 \pm 10.6 \mathrm{~cm} \mathrm{H}_{2} \mathrm{O}$. A preoperative Qmax of $\geq 6 \mathrm{~mL} / \mathrm{sec}$ was a predictive factor for a successful outcome, whereas a Qmax of $<6 \mathrm{~mL} / \mathrm{sec}$ was a predictive factor for postoperative CIC.

\section{Adjustable Sling Procedure}

When patients with UAB and incontinence have risk factors for voiding dysfunction after surgery, conventional MUS allows for adjustment of the sling tension by loose sling placement during surgery. However, adjustment of the tension during surgery has limitations for various postoperative outcomes according to the patient's preoperative condition. Adjustable slings are expected to have better outcomes than conventional MUS in patients with incontinence and UAB because they control tension both during and after surgery. Typically adjustable slings include transobturator adjustable tape (TOA) and the Remeex system.

Lee et al. [17] reported TOA as an effective modality for treating SUI with voiding dysfunction, which was defined as a Qmax of $\leq 12 \mathrm{~mL} / \mathrm{sec}$ with a voided volume of $\geq 100 \mathrm{~mL}$. Among patients with combined SUI and voiding dysfunction, the complete SUI cure rate was $76.7 \%$ and the satisfaction rate was $80 \%$ at 6-month follow-ups. There were no significant changes in Qmax and PVR. Only 1 patient required mesh cutting due to persistent postoperative voiding dysfunction. Jo et al. [18] showed the effects of TOA in patients with SUI and DU defined as Qmax of $<15 \mathrm{~mL} / \mathrm{sec}$. The objective cure rate in SUI with DU was $80 \%$, which was not significantly different from that of SUI only. There was no difference in the PVR in the UDS performed after surgery, but the Qmax decreased significantly from $17.0 \pm 9.41 \mathrm{~mL} / \mathrm{sec}$ to $14.1 \pm 9.8 \mathrm{~mL} / \mathrm{sec}$ in the SUI with DU group.

The Remeex system is an adjustable device that allows tension regulation at any time after surgery for SUI. A study evaluating Remeex system outcomes for patients with SUI and DU reported a treatment success rate of $81.5 \%$ over 38 months of follow-up and improved quality of life [19]. The Qmax decreased significantly after surgery from $12.6 \pm 6.3 \mathrm{~mL} / \mathrm{sec}$ to $8.9 \pm 5.7 \mathrm{~mL} / \mathrm{sec}$, but the PVR did not change significantly, and persistent urinary retention was found in about $25 \%$ of the patients in that study. Chung and Yoo [20] investigated Remeex system outcomes for SUI with female voiding dysfunction, which was defined as a Qmax of $\leq 12 \mathrm{~mL} / \mathrm{sec}$ when the voided volume was $\geq 150 \mathrm{~mL}$. The subjective surgical outcomes and patient satisfaction were not significantly different for SUI with and without voiding dysfunction. The Qmax decreased and the PVR increased slightly in both groups after 2 months of followup, but these changes were not significantly different. Although the rate of tension regulation after surgery was significantly higher in the SUI with voiding dysfunction group, the complication rate was not significantly different between the 2 groups.

\section{Surgical Treatment for Postprostatectomy Incontinence With UAB}

About $40 \%$ of the patients with postprostatectomy incontinence (PPI) have DU due to bladder denervation during radical prostatectomy [21]. The main surgical treatments for PPI are artificial urinary sphincter (AUS) and male sling [22]. Some urologists are concerned about urinary retention after these surgical treatments for PPI with UAB. However, the outcomes and proportions of increased PVR after AUS for PPI were not different between voided by straining, implying impaired detrusor contractility and normal contractility $[23,24]$. The patients with PPI who require AUS implant have low urethral resistance and do not have high PVR before treatment for SUI. The possibility of complications such as voiding difficulty due to AUS may be low in patients who void normally.

The pressure change in the urethra during the voiding phase with a male sling can be small compared to the pressure changes in the urethra when a cuff is fully deflated during voiding with AUS. Thus, some argue that insufficient detrusor contrac- 
tility cannot overcome the fixed resistance of a male sling during the voiding phase [25]. Han et al. [26] investigated the safety of male slings for PPI with impaired contractility, defined as a bladder contractility index less than 100 and insignificant PVR. Although the patients had impaired contractility, the preoperative mean PVR was $17.4 \mathrm{~mL}$, and patients emptied their bladders well, with a maximum PVR of $140 \mathrm{~mL}$. Patients with PPI and poor contractility who underwent sling procedure in that study had no difference in postoperative PVR and Qmax compared to the patients with normal contractility. Therefore, male slings can be used safely for PPI with UAB and normal urine emptying. However, there are insufficient studies on the outcomes of male slings in UAB patients with increased PVR and further research is necessary.

\section{Role of Therapeutic Modalities for UAB in Incontinence}

There are no proven standard treatment options for UAB. However, currently proposed UAB treatments, including behavioral, pharmacological, and CIC strategies can be applied when voiding symptoms due to $\mathrm{UAB}$ occur after treatment for incontinence.

\section{Pharmacotherapy}

Alpha-blockers relax smooth muscle within the bladder outlet and are effective for UAB-related bladder outlet obstruction (BOO). Alpha-blockers were also effective for LUTS and PVR in a study that enrolled patients with UAB but strictly excluded $\mathrm{BOO}$ patients [27]. Although surgical treatment such as tape incision or urethrolysis should be performed for persistent voiding dysfunction caused by obstruction after anti-incontinence surgery [28], alpha-blockers can be used for voiding dysfunction after anti-incontinence surgery related to preoperative UAB. However, alpha-blockers alone do not increase detrusor contractility in DU [29], and there is a lack of evidence regarding the efficacy of alpha-blockers in managing incontinence with UAB.

Parasympathomimetics can theoretically enhance detrusor contractility because they augment excitatory acetylcholine action between the synapses. However, parasympathomimetics are not recommended for $\mathrm{UAB}$ due to their potential adverse effects and unproven clinical efficacy [30]. Although parasympathomimetics such as bethanechol continue to be prescribed for UAB in elderly women [31], there is insufficient evidence for a role of bethanechol in $\mathrm{UAB}$ patients with incontinence.

\section{Clean intermittent catheterization}

The current mainstay of urinary retention in UAB is CIC. CIC can control incomplete bladder emptying and complications related to high PVR, but it is not a definitive treatment for UAB [32]. CIC should be recommended for urinary retention or when a patient cannot empty two-thirds of their bladder volume after anti-incontinence surgery [28]. CIC for voiding dysfunction after anti-incontinence surgery is conducted 3 to 4 times daily until the PVR decreases to less than $100 \mathrm{~mL}$ or is at most half of the voided volume [33]. Although the results may vary depending on the preoperative patient characteristics, more than $20 \%$ of the patients required CIC after a MUS in a study of SUI patients with DU who had more than $180 \mathrm{~mL}$ mean preoperative PVR [16]. Incontinence patients with UAB who can only empty their bladder through CIC are more likely to maintain CIC after incontinence treatment. Patients with neurogenic SUI related to spinal cord injury who can empty their bladder only by CIC had a high continent rate after implantation of an AUS, although CIC had to be maintained after surgery [34].

\section{Future therapies}

Since there are no definitive treatments for $\mathrm{UAB}$, potential therapies such as stem cell therapy or gene therapy are in clinical trials for the management of UAB. Stem cell therapy for UAB is based on the improvement of detrusor contractility and voiding through regeneration of the detrusor smooth muscle [35]. Exogenous stem cell factor of neural and smooth muscle origin restored and improved detrusor contraction in rats with $\mathrm{UAB}$ by increasing the number of interstitial cells of Cajal [36]. The clinical efficacy and safety of intradetrusor injections of autologous muscle-derived cells for UAB were reported in a pilot study with humans [37]. Stem cells can restore the urethral sphincter function, and several clinical trials have shown the potential of stem cell therapy for managing SUI [38]. Although there is currently insufficient evidence, the application of stem cell therapy to both detrusor smooth muscle and urethral sphincter smooth muscle may be used to treat UAB patients with incontinence.

Gene therapy for UAB has been conducted experimentally using the concept of delivery genes that increase detrusor smooth muscle contractility. Goins et al. [39] reported that nerve growth factor gene delivery to sensory ganglia cells innervating the bladder using herpes simplex virus decreased the PVR in rats with neurogenic DU. Several studies investigating the genetic factors of SUI and developing future targeted therapies for SUI have reported the role of genes such as growth fac- 
tor receptor-bound protein 2 [40]. Future research on gene therapy may be applicable to the treatment of incontinence with UAB.

\section{Management of DHIC}

The control of DHIC patients who have UUI and poor detrusor contractility is challenging. Since the DHIC is common in the elderly population who have multifactorial causes of lower urinary tract dysfunction, individual situations in patients should be considered when treating DHIC. DHIC patients who suffer from urinary retention need to catheterization for bladder emptying. However, in DHIC patients who showed UUI without urinary retention, other methods can be tried to control the symptoms.
Beta3-adrenergic receptor agonists that can relax the bladder without blocking of acetylcholine activity during detrusor contraction have been introduced for the management of DHIC with improvement in urgency and voiding efficiency [41]. However, there is a lack of evidence on the efficacy for UUI in DHIC yet. Intravesical onabotulinumtoxin A injection that is known to be effective for refractory $\mathrm{OAB}$ can be used in patients with DHIC. Although the subjective urgency symptom improved without an increased risk of adverse events, onabotulinumtoxin A has not shown efficacy for UUI in DHIC [42].

Sacral neuromodulation has the potential to control both UUI and compromised detrusor contractile function. Hennessey and Hoag reported that sacral neuromodulation for patients with DHIC could ameliorate OAB symptoms and de-

Table 1. Summary of outcomes of surgical treatments for stress urinary incontinence with underactive bladder

\begin{tabular}{|c|c|c|c|c|c|}
\hline Trials & $\begin{array}{l}\text { No. of } \\
\text { patients }\end{array}$ & $\begin{array}{l}\text { Follow-up } \\
\text { duration }\end{array}$ & $\begin{array}{l}\text { Definition of } \\
\text { UAB or DU }\end{array}$ & Efficacy outcome & Safety outcome \\
\hline \multicolumn{6}{|l|}{ TOT } \\
\hline Kim and Kim [14] & 41 & $\geq 2$ Years & $\begin{array}{l}\text { Qmax }<15 \mathrm{~mL} / \mathrm{sec} \text { and } \\
\text { PdetQmax }<20 \mathrm{~cm} \mathrm{H}_{2} \mathrm{O}\end{array}$ & $\begin{array}{l}\text { Cure rate: } 88 \%, \\
\text { satisfaction rate } 71 \%\end{array}$ & $\begin{array}{l}\text { Change of PVR: } 16.1 \pm 32.3 \mathrm{~mL} \\
\rightarrow 26.1 \pm 27.9 \mathrm{~mL}(\mathrm{P}<0.05)\end{array}$ \\
\hline Natale et al. [15] & 118 & 76 Months & $\begin{array}{l}\text { PdetQmax+Qmax } \\
<30 \mathrm{~cm} \mathrm{H}_{2} \mathrm{O}\end{array}$ & $\begin{array}{l}\text { Cure rate: } 82 \% \text { in DU vs. } \\
84 \% \text { in control group } \\
(\mathrm{P}=1.000)\end{array}$ & $\begin{array}{l}\text { Postoperative voiding difficulty: } 7.3 \% \\
\text { Postoperative VD: } 36 \% \text { in DU vs. } 16 \% \text { in } \\
\text { control group }(\mathrm{P}=0.0339)\end{array}$ \\
\hline \multicolumn{6}{|l|}{ Retropubic MUS } \\
\hline Ong and Kuo [4] & 403 & 97 Months & $\begin{array}{l}\text { Based on preoperative } \\
\text { videourodynamics }\end{array}$ & $\begin{array}{l}\text { Cure rate: } 79.4 \% \text { in DU vs. } \\
84.5 \% \text { in stable bladder }\end{array}$ & $\begin{array}{l}\text { Change of PVR: } 182.2 \pm 291.3 \mathrm{~mL} \\
\rightarrow 214 \pm 202 \mathrm{~mL} \text { in DU vs. } 35.3 \pm 6.3 \mathrm{~mL} \\
\rightarrow 30.2 \pm 50 \mathrm{~mL} \text { in stable bladder }\end{array}$ \\
\hline Chen et al. [16] & 71 & 12 Months & $\begin{array}{l}\text { Qmax }<15 \mathrm{~mL} / \mathrm{sec} \text { and } \\
\text { PdetQmax }<20 \mathrm{~cm} \mathrm{H}_{2} \mathrm{O}\end{array}$ & Improvement rate: $76 \%$ & $\begin{array}{l}\text { Preoperative Pdet and Qmax in no } \\
\text { improvement group: } 4.87 \pm 7.17 \mathrm{~cm} \mathrm{H}_{2} \mathrm{O} \\
\text { and } 5.00 \pm 6.07 \mathrm{~mL} / \mathrm{sec}\end{array}$ \\
\hline \multicolumn{6}{|l|}{ TOA } \\
\hline Lee et al. [17] & 30 & 6 Months & $\begin{array}{l}\text { Qmax } \leq 12 \mathrm{~mL} / \mathrm{sec} \text { with a } \\
\text { voided volume } \geq 100 \mathrm{~mL}\end{array}$ & $\begin{array}{l}\text { Cure rate: } 76.7 \% \\
\text { satisfaction rate: } 80 \%\end{array}$ & $\begin{array}{l}\text { No significant change in Qmax and PVR, } \\
\text { persistent VD: } 3.3 \%\end{array}$ \\
\hline Jo et al. [18] & 30 & 1 Year & Qmax $<15 \mathrm{~mL} / \mathrm{sec}$ & Cure rate: $80 \%$ & $\begin{array}{l}\text { Change of PVR: } 263.3 \pm 78.2 \mathrm{~mL} \rightarrow 317.9 \pm 187.6 \\
\mathrm{~mL}(\mathrm{P}=0.268) \text {, change of } \mathrm{Qmax} 17 \pm 9.4 \mathrm{~mL} / \\
\mathrm{sec} \rightarrow 14.1 \pm 9.8 \mathrm{~mL} / \mathrm{sec}(\mathrm{P}=0.044)\end{array}$ \\
\hline \multicolumn{6}{|l|}{ Remeex system } \\
\hline Ko et al. [19] & 27 & 38 Months & $\begin{array}{l}\text { Definition by } 2002 \text { ICS } \\
\text { standardization report }\end{array}$ & Cure rate: $81.5 \%$ & $\begin{array}{l}\text { Change of PVR: } 72.1 \pm 88.8 \mathrm{~mL} \rightarrow 56.8 \pm 87.5 \mathrm{~mL} \\
(\mathrm{P}=0.717) \text {, change of } \mathrm{Qmax} 12.6 \pm 6.3 \mathrm{~mL} / \\
\mathrm{sec} \rightarrow 8.9 \pm 5.7 \mathrm{~mL} / \mathrm{sec}(\mathrm{P}=0.044)\end{array}$ \\
\hline Chung and Yoo [20] & 102 & 43.9 Months & $\begin{array}{l}\text { Qmax } \leq 12 \mathrm{~mL} / \mathrm{sec} \text { with a } \\
\text { voided volume } \geq 150 \mathrm{~mL}\end{array}$ & $\begin{array}{l}\text { Cure rate: } 53.6 \% \text { in VD vs. } \\
62.2 \% \text { in control group } \\
(\mathrm{P}=0.78)\end{array}$ & $\begin{array}{l}\text { Change of PVR: } 6.46 \pm 50.91 \mathrm{~mL} \text { in VD vs. } \\
6.81 \pm 32.94 \mathrm{~mL} \text { in control group }(\mathrm{P}=0.968) \text {, } \\
\text { change of Qmax: }-0.36 \pm 1.93 \mathrm{~mL} / \mathrm{sec} \text { in } \\
\text { VD vs. }-1.65 \pm 7.29 \mathrm{~mL} / \mathrm{sec} \text { in control } \\
\text { group }(\mathrm{P}=0.165) \\
\text { Complication rate: } 25.0 \% \text { in } \mathrm{VD} \text { vs. } 20.3 \% \\
\text { in control group }(\mathrm{P}=0.604)\end{array}$ \\
\hline
\end{tabular}

UAB, underactive bladder; DU, detrusor underactivity; TOT, transobturator tape; Qmax, maximal flow rate; PdetQmax, detrusor pressure at maximal flow rate; PVR, postvoid residual volume; VD, voiding dysfunction; MUS, midurethral sling; TOA, transobturator adjustable tape; ICS, International Continence Society. 
crease in PVR although they did not show an improvement in UUI due to the small patient numbers [43].

\section{CONCLUSIONS}

There is no definitive research establishing the most appropriate management for incontinence with UAB. The current surgical treatments for SUI may also be effective in patients with UAB. The results of trials for SUI with UAB are summarized in (Table 1). Since proper tension is important for treating SUI with $\mathrm{UAB}$, adjustable slings may play an important role in patient management. In addition, other treatments for UAB may be applied to voiding dysfunction after incontinence treatment to improve patient voiding symptoms. The possibility of controlling UUI related to DHIC using sacral neuromodulation has also been consistently suggested. However, further research is needed to establish evidence for the efficacy and safety of treatments for incontinence with $\mathrm{UAB}$ and to improve patient quality of life.

\section{AUTHOR CONTRIBUTION STATEMENT}

\author{
- Conceptualization: JCK \\ - Formal Analysis: KJC \\ - Investigation: KJC \\ - Methodology: KJC \\ - Project Administration: JCK \\ -Writing-Original Draft: KJC \\ -Writing-Review \& Editing: JCK
}

\section{REFERENCES}

1. Murukesu RR, Singh DKA, Shahar S. Urinary incontinence among urban and rural community dwelling older women: prevalence, risk factors and quality of life. BMC Public Health 2019;19(Suppl 4):529.

2. Dewulf K, Abraham N, Lamb LE, Griebling TL, Yoshimura N, Tyagi $\mathrm{P}$, et al. Addressing challenges in underactive bladder: recommendations and insights from the Congress on Underactive Bladder (CURE-UAB). Int Urol Nephrol 2017;49:777-85.

3. Jeong SJ, Kim HJ, Lee YJ, Lee JK, Lee BK, Choo YM, et al. Prevalence and clinical features of detrusor underactivity among elderly with lower urinary tract symptoms: a comparison between men and women. Korean J Urol 2012;53:342-8.

4. Ong HL, Kuo HC. Bladder dysfunction does not affect long-term success rate of the retropubic suburethral sling procedure in wom- en with stress urinary incontinence. Low Urin Tract Symptoms 2019;11:O168-73.

5. Aizawa N, Igawa Y. Pathophysiology of the underactive bladder. Investig Clin Urol 2017;58(Suppl 2):S82-9.

6. Deng DY. Urinary incontinence in women. Med Clin North Am 2011;95:101-9.

7. Li X, Liao LM, Chen GQ, Wang ZX, Lu TJ, Deng H. Clinical and urodynamic characteristics of underactive bladder: data analysis of 1726 cases from a single center. Medicine (Baltimore) 2018;97:e9610.

8. Tran H, Rutman M. Female outlet obstruction after anti-incontinence surgery. Urology 2018;112:1-5.

9. Dumoulin C, Hay-Smith J. Pelvic floor muscle training versus no treatment, or inactive control treatments, for urinary incontinence in women. Cochrane Database Syst Rev 2010;(1):CD005654.

10. Labrie J, Berghmans BL, Fischer K, Milani AL, van der Wijk I, Smalbraak DJ, et al. Surgery versus physiotherapy for stress urinary incontinence. N Engl J Med 2013;369:1124-33.

11. Ladi-Seyedian S, Kajbafzadeh AM, Sharifi-Rad L, Shadgan B, Fan E. Management of non-neuropathic underactive bladder in children with voiding dysfunction by animated biofeedback: a randomized clinical trial. Urology 2015;85:205-10.

12. Minardi D, d’Anzeo G, Parri G, Polito M Jr, Piergallina M, El Asmar Z, et al. The role of uroflowmetry biofeedback and biofeedback training of the pelvic floor muscles in the treatment of recurrent urinary tract infections in women with dysfunctional voiding: a randomized controlled prospective study. Urology 2010;75:1299304.

13. Ford AA, Rogerson L, Cody JD, Ogah J. Mid-urethral sling operations for stress urinary incontinence in women. Cochrane Database Syst Rev 2015;(7):CD006375.

14. Kim SJ, Kim JC. Influence of preoperative detrusor underactivity on the continence rate and satisfaction after midurethral sling patient with stress urinary incontinence. Low Urin Tract Symptoms 2010;2:95-9.

15. Natale F, Illiano E, Zucchi A, Balzarro M, La Penna C, Costantini E. Transobturator mid-urethral sling in females with stress urinary incontinence and detrusor underactivity: effect on voiding phase Int Urogynecol J 2019;30:1519-25.

16. Chen CJ, Yeoh SC, Yeh HT, Hsiao SM, Kuo HC. Surgical results in women with detrusor underactivity and stress urinary incontinence undergoing suburethral sling procedure-Predictive factors for successful outcome. Low Urin Tract Symptoms 2020;12:143-9.

17. Lee SY, Lee YS, Lee HN, Choo MS, Lee JG, Kim HG, et al. Transobturator adjustable tape for severe stress urinary incontinence and stress urinary incontinence with voiding dysfunction. Int Uro- 
gynecol J 2011;22:341-6.

18. Jo DG, Yang SA, Seo JT. Effects of transobturator adjustable tape sling procedure on the therapeutic outcome in patients with stress urinary incontinence and detrusor underactivity. Int Neurourol J 2010;14:20-5.

19. Ko KJ, Suh YS, Sung HH, Ryu GH, Lee M, Lee KS. Assessing the Readjustable Sling Procedure (Remeex System) for female stress urinary incontinence with detrusor underactivity. Int Neurourol J 2017;21:116-20.

20. Chung JW, Yoo ES. Efficacy and safety of a readjustable midurethral sling (Remeex system) for stress urinary incontinence with female voiding dysfunction. Investig Clin Urol 2017;58:127-33.

21. Chung DE, Dillon B, Kurta J, Maschino A, Cronin A, Sandhu JS. Detrusor underactivity is prevalent after radical prostatectomy: a urodynamic study including risk factors. Can Urol Assoc J 2013;7:E33-7.

22. Radadia KD, Farber NJ, Shinder B, Polotti CF, Milas LJ, Tunuguntla HSGR. Management of postradical prostatectomy urinary incontinence: a review. Urology 2018;113:13-9.

23. Gomha MA, Boone TB. Voiding patterns in patients with postprostatectomy incontinence: urodynamic and demographic analysis. J Urol 2003;169:1766-9.

24. Trigo Rocha F, Gomes CM, Mitre AI, Arap S, Srougi M. A prospective study evaluating the efficacy of the artificial sphincter AMS 800 for the treatment of postradical prostatectomy urinary incontinence and the correlation between preoperative urodynamic and surgical outcomes. Urology 2008;71:85-9.

25. Comiter CV, Dobberfuhl AD. The artificial urinary sphincter and male sling for postprostatectomy incontinence: which patient should get which procedure? Investig Clin Urol 2016;57:3-13.

26. Han JS, Brucker BM, Demirtas A, Fong E, Nitti VW. Treatment of post-prostatectomy incontinence with male slings in patients with impaired detrusor contractility on urodynamics and/or who perform Valsalva voiding. J Urol 2011;186:1370-5.

27. Yamanishi T, Yasuda K, Kamai T, Tsuji T, Sakakibara R, Uchiyama T, et al. Combination of a cholinergic drug and an alpha-blocker is more effective than monotherapy for the treatment of voiding difficulty in patients with underactive detrusor. Int J Urol 2004;11:88-96.

28. Celik H, Harmanlı O. Evaluation and management of voiding dysfunction after midurethral sling procedures. J Turk Ger Gynecol Assoc 2012;13:123-7.

29. Sekido N, Kida J, Wakamatsu D, Okada H, Matsuya H. Effects of al antagonist and cholinesterase inhibitor on cystometric parameters in lumbar canal stenosis rats with underactive bladder. Urology 2014;84:1248.e9-15.

30. Barendrecht MM, Oelke M, Laguna MP, Michel MC. Is the use of parasympathomimetics for treating an underactive urinary bladder evidence-based? BJU Int 2007;99:749-52.

31. Gaitonde S, Malik RD, Christie AL, Zimmern PE. Bethanechol: is it still being prescribed for bladder dysfunction in women? Int J Clin Pract 2019;73:e13248.

32. Yamany T, Elia M, Lee JJ, Singla AK. Female underactive bladder current status and management. Indian J Urol 2019;35:18-24.

33. Siddighi S, Karram MM. Surgical and nonsurgical approaches to treat voiding dysfunction following antiincontinence surgery. Curr Opin Obstet Gynecol 2007;19:490-5.

34. Bersch U, Göcking K, Pannek J. The artificial urinary sphincter in patients with spinal cord lesion: description of a modified technique and clinical results. Eur Urol 2009;55:687-93.

35. Chai TC, Kudze T. New therapeutic directions to treat underactive bladder. Investig Clin Urol 2017;58(Suppl 2):S99-106.

36. Feng J, Gao J, Zhou S, Liu Y, Zhong Y, Shu Y, et al. Role of stem cell factor in the regulation of ICC proliferation and detrusor contraction in rats with an underactive bladder. Mol Med Rep 2017;16:1516-22.

37. Levanovich PE, Diokno A, Hasenau DL, Lajiness M, Pruchnic R, Chancellor MB. Intradetrusor injection of adult muscle-derived cells for the treatment of underactive bladder: pilot study. Int Urol Nephrol 2015;47:465-7.

38. Shin JH, Ryu CM, Yu HY, Shin DM, Choo MS. Current and future directions of stem cell therapy for bladder dysfunction. Stem Cell Rev Rep 2020;16:82-93.

39. Goins WF, Yoshimura N, Phelan MW, Yokoyama T, Fraser MO, Ozawa $\mathrm{H}$, et al. Herpes simplex virus mediated nerve growth factor expression in bladder and afferent neurons: potential treatment for diabetic bladder dysfunction. J Urol 2001;165:1748-54.

40. Isali I, Mahran A, Khalifa AO, Sheyn D, Neudecker M, Qureshi A, et al. Gene expression in stress urinary incontinence: a systematic review. Int Urogynecol J 2020;31:1-14.

41. Lee CL, Kuo HC. Efficacy and safety of mirabegron, a $\beta 3$-adrenoceptor agonist, in patients with detrusor hyperactivity and impaired contractility. Low Urin Tract Symptoms 2019;11:O93-7.

42. Wang CC, Lee CL, Kuo HC. Efficacy and safety of intravesical onabotulinumtoxinA injection in patients with detrusor hyperactivity and impaired contractility. Toxins (Basel) 2016;8:82.

43. Hennessey DB, Hoag N, Gani J. Sacral neuromodulation for detrusor hyperactivity with impaired contractility. Neurourol Urodyn 2017;36:2117-22. 